\title{
Ecological Analysis of Anthropogenic Impact on Natural Landscapes of the Baikal Region
}

\author{
Oleg A. Imetkhenov, Galina P. Dondukova, and Bato Ts. Dondukov
}

\begin{abstract}
The article deals with the issues of anthropogenic impact on natural landscapes of the Baikal region through mining and agricultural development of the region. A brief description of environmental problems of the region is given, the impact of human activities on the environment of the Baikal region is assessed. The authors take into consideration specific cases of harmful environmental management that can lead to ecological disbalance and landscape degradation. In such a way, the scale and nature of mining increased significantly in recent years. In order to preserve the natural landscape, it is necessary to carry out geological work with minimum losses, and perform thorough environmental and geochemical expertise. In agriculture, harsh natural conditions of Transbaikalia (sharp continental climate, low rainfall) necessitate more efficient farming methods - melioration, which is aimed at radical improvement of land, however, fails at times.
\end{abstract}

Index Terms-Anthropogenic impact, Baikal region, ecological balance, landscape degradation, deforestation, wetlands, soil contamination.

\section{INTRODUCTION}

The Baikal region is a region of intensive economic development, where all natural landscapes from northern forest-steppe of Vitim plateau to steppe zone of the Selenga middle mountain region are experiencing the negative anthropogenic impact in various degrees. The aim of this article is to describe and assess the anthropogenic impact of mining and agricultural development on natural landscapes of the Baikal region. Starting with an overview of natural landscapes and their use in various parts of the Baikal region, we consider specific cases of harmful environmental management that can lead to ecological disbalance and landscape degradation.

The Baikal region is located practically in the central part of Russia and has direct access to the borders with Mongolia and China. On its territory there are two railway lines connecting West and East - Baikal-Amur mainline and Trans-Siberian railway. The area of the Baikal region is 315 thousand $\mathrm{km}^{2}, 8.5 \%$ lie in the Irkutsk Region, $74.1 \%$ - in the Republic of Buryatia, and $17.4 \%$ belong to Zabaykalsky Krai (Appendix 1). The region includes 31.7 thousand $\mathrm{km}^{2}$ of the water area of the lake Baikal (9.3\% of the Baikal region),

Manuscript received June 22, 2019; revised November 1, 2019. This work was supported in part by RSF, project №19-18-00412.

O. A. Imetkhenov is with the Department of Ecology, Subsoil Use and Life Safety, East-Siberia State University of Technology and Management, Ulan-Ude, 670013, Russia (e-mail: imetchenov@ rambler.ru).

G. P. Dondukova and B. Ts. Dondukov are with the Department of Organization and Management of Scientific Researches, East-Siberia State University of Technology and Management, Ulan-Ude, 670013, Russia (e-mail: galina.dondukova11@gmail.com,dondukovb@gmail.com).
$40 \%$ of which are located in the Irkutsk Region, $50 \%$ in Buryatia and 10\% in Zabaykalsky Krai. In 1996, Lake Baikal was included to the list of World Heritage Sites. In 1999 the federal law "On Protection of Lake Baikal" was passed.

A variety of mineral deposits is explored in this area. Coal reserves are confined to the Mesozoic intermountain basin of Western Transbaikalia (Okino-Klyuchevskoe brown coal field, Tugnuyskoe and Nikolskoe coal deposits). Predominant part of coal layers is shallow; therefore, open mining is widely practiced. Small coal reserves, also mined openly, are found in the basin of the Dzhida river, as well as in the upper Uda river [1].

Among the metallic minerals iron ore is mined in Kurbino-Eravninsky iron-ore district [2], manganese - in Garginskoe of Ikatsky ridge and Taloyskoye in Eravninsky basin).

Rare and non-ferrous metals are represented by fields of tungsten and molybdenum (Kholtoson and Inkurskoe fields in the valley of the Dzhida river), molybdenum (Orekitkanskoe in the Northern Baikal region, Zharchikhinskoe in the central part of Western Transbaikalia), lead and zinc (Kholkinskoe and Ozernoe in Baikal mountain range and in the upper Uda river), gold (Zun-Kholbinskoe and Samartinskoe in the East Sayan, Irokindinskoe and Kedrovskoe in the Vitim plateau) [3].

Non-metallic minerals include fluorites (Naranskoe field in Western Transbaikalia, at the foot of Khamar-Daban ridge), quartz (Cheremshanskoe on Sea ridge), marble and lapis-lazuli (Slyudyanskoe on the southern coast of Baikal).

Significant reserves of apatite (Oshurkovskoe field near Ulan-Ude), chrysotile asbestos (Molodezhnoe in Yuzhno-Muysky ridge), graphite (Botogolskoe in the East Sayan and Boyarskoe on the southern coast of Baikal) are explored [4].

In agriculture, almost all steppe and significant part of forest-steppe areas of the region are partially plowed up and are subject to pasture degradation. Floodplain and drainage forests of the Baikal region are almost clearcut. As a result, hundreds of small rivers dried up, some rivers and lakes shallowed. A number of springs dry up in dry years and flood in rainy years. In other words, agricultural development led to ecological imbalance in the system nature-man.

\section{MATERIALS AND METHODS OF RESEARCH}

Ecological analysis of anthropogenic impact on the natural landscapes of the Baikal region is based on the archival, statistical, cartographic materials, as well as authors' research.

Extreme natural conditions on the territory of the Baikal 
region and their sharp variation even in small areas predetermined vulnerable and easy-to-reduce natural environment. First of all, the lake Baikal itself, surrounded by peculiar mountain ranges on all sides can be characterized with extremely unstable ecosystem. In addition, the region is marked by great variety of natural zones: forest-tundra landscapes in the north are replaced by steppe and semi-desert expanses in the south, along the mountain ranges the taiga extends to the southern borders of Buryatia and Northern Mongolia, whereas steppes go down north to South Yakutia through intermountain basins. What is more, in Barguzinsky basin dry steppes are surrounded by high, taiga-covered mountains; in southern Transbaikalia as well, taiga and dry steppes intersect in some areas. Such disorder of lowland zones is typical for the Baikal region, especially for Transbaikalia.

Vertical zonality is also very complex: semi-desert landscapes at the foot of the mountains are replaced by steppe, forest-steppe, taiga, mountain-forest-tundra, mountain-tundra up to the zones of bald mountains with glaciers. Such extremely vulnerable landscapes require close attention and special protection system.

There is a number of different types of anthropogenic influence on natural environment of the plains, foothills and mountains. Taiga forests experienced the most extensive landscape transformation. Deforestation is considered as the primary environmental consequence of a human moving deeper into the forest-steppe and taiga zones. Today it is hard to believe that most of the Selenga middle mountains were once covered by continuous light-coniferous forest. Deforestation has intensified in recent years. Clear cutting began in the middle mountain part of the Khamar-Daban, Kurbinsky, Ulan-Burgasy and Ikatsky ranges. Nowadays, forest coverage of the southern part of Selenginskoe highlands is only about $25 \%$ [5].

Ill-conceived drainage of wetlands resulted in disbalance of water regime in Borgoi, Tunkinskaya, Ivolginskaya, Tugnui and other basins of the Eastern Baikal and Western Transbaikalia. Degradation of once beautiful lakes of Buryatia - Gusinoe, Shchuchie, Kotokelskoe, system of Eravninsky and Bauntovsky lakes continues due to pollution by industrial and household waste and wastewater of settlements, Gusinoozersk hydroelectric power station. At the same time, ground and surface waters are polluted with sharp contamination of soil and vegetation cover and activation of exogenous processes in areas where open mining takes place: Zun-Kholbinskoe (East Sayan) and Irokindinskoe (Vitim Plateau) ore gold, Tugnui coal (Selenginskoe middle mountains), Cheremshan quartzite on the southeastern coast of Baikal, Slyudyansk marble and lapis-lazuli on the southern shore of Lake Baikal, alluvial gold, polymetallic ores and uranium on Vitimsky highland.

An example of low assessment of negative impact on the environment is Oshurkovskoe apatite field. In strive to quick construction of the Trans-Baikal Apatite Plant (ZAK) near the Selenga river in $20 \mathrm{~km}$ from Ulan-Ude assessment of anthropogenic impact on the environment was ignored. Having invested more than 80 million rubles (at prices of 1982), it turned out that the extraction of ore was supposed to be carried out in explosive manner in close proximity to the city. That would undoubtedly lead to significant pollution of the Selenga river and Ulan-Ude with suspended mineral particles and dust. The plant was first stopped, and later liquidated. The example with ZAK showed the necessity of developing a uniform methodology of ecological assessment of all fields involved in the economic activity. In such cases, it is essential to show the degree of environmental hazard, i.e. the presence of harmful and toxic components in the ores, minerals which are unstable in landscape and climatic conditions, occurrence of interacting compounds with the environment [6].

\section{RESULTS}

The results of this study point out several negative impacts on natural landscapes of the Baikal region that can lead to landscape degradation (Appendix 2, Appendix 3) [7].

First, there has been observed sharp surface damage and destruction of topsoil as a result of irrational environmental management. Secondly, air and surface waters are polluted in mining areas; thirdly, all these violations contribute to activation of erosion processes, dehydration of the surrounding area, etc.

As noted above, the region is rich in mineral deposits. Some deposits are under development (Slyudyanskoe, Irokindinskoe, Yermakovskoe, Zun-Kholbinskoe, Samartinskoe), others are being prepared for mining (Ozernoe, Inkurskoe and Kholtosonskoe, Molodezhnoe). A small group of deposits will not be developed in the near future (Kholodninskoe, Oshurkovskoe, Zharchikhinskoe).

All fields of Western Transbaikalia and Cisbaikalia (in the case of mining according to the norms of sanitary and hygienic danger) can be divided into three groups: environmentally hazardous, less hazardous, and low-hazardous/non-hazardous.

The majority of fields involved in the economic activity belong to the group of low-hazardous and non-hazardous for the environment. These are mainly deposits of building materials for the cement industry (limestones - Timlyuyskoe, chemically pure limestones - Bilyutinskoe, perlites Mukhor-Talinskoe field). Environmental pollution is associated only with increased dustiness of chemically inert components. The greatest pollution is attributed to the activities of Dzhidinsky molybdenum-tungsten plant. Accumulated waste of the plant is drained into a hydrographic network and fixed for many kilometers downstream the Modonkul river, which flows into the Dzhida river [8].

Two out of four deposits in Transbaikalia are in operation, one is closing down, another one is in preparation for development. The first two fields, Cheremshansk deposit of quartzite and Tugnuyskoe coal deposit, are low-hazardous. Both do not contain harmful or active ingredients. The impact of their development on the environment is associated exclusively with dust. The presence of sulfur in the Tugnuyskoe deposit causes its partial oxidation forming acidic waters, but considerable distance from lake Baikal and low concentration of active sulfur reduce the danger.

The greatest danger is the Kholodninskoe pyrite lead-zinc 
deposit, the development of which is not expected in the near future due to its location within the boundaries of the Central ecological zone of lake Baikal. According to GOST 17.4.1.02-83 "Environmental protection. Soils. Classification of chemicals for pollution control," its ores contain components of all four classes of hygienic hazard (lead, zinc, copper, cadmium). The open method of mining the field can cause intensive dust contamination of large areas with a sulfide material containing a large amount of harmful components. Decomposition of sulfides can lead to acid pollution of soils and water bodies. Rainwash of sulphide fraction in the Kholodnaya and Tyya rivers flowing directly into Baikal can pose a serious danger. High hypsometric position of the Kholodninskoe field, located near the lake Baikal requires its thorough environmental expertise [9].

Lake-pyrite lead-zinc deposit located outside the catchment area of the lake Baikal will not have a significant impact on the pollution of its waters. But at the same time, the presence of eastern winds in a certain time of the year (spring and autumn) may cause transfer of sulfide dust fraction containing such harmful components as zinc, cadmium, thallium, barium, sulfur. In case of active decomposition of sulphides in tailing dumps, inwash of sulfur compounds and acid rains become possible. This field also requires thorough environmental and geochemical expertise. At present, IFC Metropol - Ozernoe LLC is working on the project of field development and is planning to launch the mine in 2022 [10], [11].

The development of Zharchikhinsky molybdenum deposit, which is in close proximity to the Selenga river, is quite hazardous. Since it is located on the watershed part of the Tsagan-Dabansky Ridge, it can lead to a wide dispersion of dust fraction containing increased amount of fluorite sulfites and aluminofluorides, which are not sufficiently stable in exogenous conditions. Tailings and waste from the concentration plant can be dangerous to the nearest water reservoirs [12]. A certain risk can cause the development of Egitinsky fluorite field, which is located on the territory of the Yeravninsky district of the Republic of Buryatia [13].

Beside ecological and geochemical expertise the study of exploitation danger of the deposits demands systematization of objects and zoning of the territory according to the degree of resistance to possible anthropogenic impact [14].

What is more, in order to protect the most unique deposits (or their parts) from destruction, it is necessary to organize geological monuments, and in some cases mineralogical museums-national parks [15]. The greatest scientific value and aesthetic appeal of deposits lies in the variety of minerals Many deposits of rare mineral formations with natural exits to the surface are declared as specially protected natural territories. However, not all deposits can be classified as protected objects, but only a small part of them in the form of small sections and outcrops.

Deforestation is another ecological problem of Baikal region where woods take water regulating function for an ecosystem of the Lake Baikal. Deforestation "unleashed" foothill erosion, which has dramatically increased the washing of fine earth in river systems. In addition, water availability on the territories has significantly decreased. If earlier the water stayed on after the summer rains and was absorbed deep into the soil, now it quickly slides down in several days, and even hours, causing catastrophic floods on large plain areas. The years 1869, 1904, 1932, 1936, 1940, 1971, 1973, 1985, 1988, 1991 and 1993 turned out to be extremely unfavorable. In such a way, for example, as a result of intensive rains there were floods in July (1932, 1936, 1971, 1973, 1983, 1988 and 1991), September (1990) and August (1993) in Cisbaikalia and Transbaikalia [16]. In June, 2019 heavy rains in three districts of Irkutsk region (Nizhneudinsk, Taishet, Tulun) led to flood on the rivers Ina, Iya, Oka and Uda. 109 settlements with population of 42760 people were flooded; 12 bridges were destroyed; 25 people died [17].

Deforestation in the valleys of the Selenga river and its tributaries resulted in aridization, desertification and noticeable expansion of the range of ephemeral vegetation on the mountain slopes. The preserved forest lands in the form of insignificant islands in the steppe zone no longer have any real environment-forming value. In addition, the continuous plowing of the riverine low-lying areas during 1980-1990 and active grazing of livestock (especially sheep) sharply limited the possibilities of reforestation and caused widespread wormwood-steppe groups in the place of former forest areas.

The cutting of forests on the territory of Baikal region significantly violated the ecological balance and stimulated sharp acceleration of mass and energy exchange in the nature-man system. Washing of fine earth into the rivers valleys in the form of mudflows and landslides turned into "usual" affair. Dangerous mudflows were observed in the summers of 1934, 1960, 1962, 1971, 1974, 1983, 2004, and 2014. The most intensively mudflows take place in the mountains and happen here every $10-15$ years. Over the past 115 years, they have repeatedly destroyed the railroad tracks, station structures, bridges, residential buildings, forests, agriculturally used areas, etc. In such a way, mudflows of summer 1971 were noted even along those river valleys where there were no any mudflows for the last 115 years, i.e. since the construction of the Circum-Baikal segment of the East-Siberian railway. Powerful mudslides, reinforced by accumulation of water and mud-stone material behind the canvas of the newly built Irkutsk-Ulan-Ude highway, demolished most of the bridges in the Slyudyanka-Mysovaya section, forming large debris cones. That mudflow destroyed the railroad over one kilometer long. As a result of natural disasters, the movement of trains and vehicles was paralyzed for 8 days [18]. In 2014, mudflows descended from the slopes of the Tunkinsky ridge of the Sayan mountain system to the Tunkinsky intermountain basin on the territory of Arshan recreation area of federal significance. Six people were injured, 1 person died. About 100 buildings were significantly damaged. According to official data of the Ministry of Emergency Situations of the Republic of Buryatia, the amount of damage was estimated at more than 200 million rubles [19].

Arid conditions during spring-summer period as well as prevalence of pine trees create fire-prone environments in the Baikal region. Since 2000 the territory of Eastern Siberia suffers from drought. Extreme weather conditions (lack of 
rainfall and heat wave) together with decrease in water level of the basin of the Lake Baikal result in accelerated drying of a ground cover and increase in dry natural fuel in the forest. The most catastrophic fires were observed in 2003, 2009 and 2015. Extremely low water level of the basin of the Lake Baikal in 2015 led to destructive wildfires, by quantity (3162 units), as well as by the area of burned-down woods (1290 thousand hectares). According to the official sources, the main reasons of forest fires are local population $-81.3 \%$, thunderstorms $-14.1 \%$, agricultural burning $-4.6 \%$ [20], [21].

Thus, disturbance of mountain-valley balance as a result of catastrophic natural processes, further enhanced by intensive economic activity, significantly changes the natural conditions in the region and upsets the environmental balance established over the centuries.

The landscape diversity of the natural environment of the Baikal region, where mountain Alpine meadows border with feather-wormwood steppes, since ancient times allowed Transbaikalian cattle breeders to combine stall, semi-nomadic and distant-nomadic cattle breeding. At the end of the 19th century, on the territory occupied by the Republic of Buryatia, the population of 310 thousand inhabitants kept up to 570 thousand sheep and goats, 640 thousand heads of cattle, 260 thousand horses [22]. In the late 1980 s, with a population of about one million people, the number of grazing animals significantly decreased, except for sheep (1600 thousand of sheep, 551 thousand of cows, 63 thousand of horses) [23]. In recent years, unsystematic grazing of livestock has caused pasture deterioration, its low feed capacity, which resulted in decrease of total livestock population.

However, the main reason of the decline of livestock lies in the transition from distant-nomadic one to stall method of grazing associated with sedentary lifestyle. Once developed method of livestock breeding survived only in some areas of south Buryatia (the upper Dzhida river and foothills of the East Sayan).

Wind spraying caused by overgrazing of cattle also significantly impacts on the steppe and forest-steppe landscapes of the Baikal region. A particularly destructive impact of overgrazing is noticed in dry valleys of Transbaikalia and the valleys of large rivers and intermountain basins of Baikal region.

Overgrazing results in blowing of upper horizon of dry salt flats, a mixture of dust particles and salt crystals. In some cases, the blowing continues to the groundwater, whereas the air above the saline areas is dusty. Such phenomena are observed in the steppe territories of the Selenga middle mountains, in the Barguzin valley and in the Tazheranskaya steppe on the western coast of Baikal. In addition, due to overgrazing of sheep, soil salinization is also observed. Such disturbed soils usually swell when moistened, and crack when dry.

The critical situation in livestock breeding was aggravated by mistakes of federal and regional economic policies. We can distinguish several stages of agriculture "modernization," which led to the collapse and impoverishment of peasants, namely:

- massive collectivization of peasant farms in the 1920-30s; - primitive soil epic in the 1950 s;
- -forced introduction of "advanced" methods for land fertility improvement and sowing of agricultural crops unacceptable in the extreme natural conditions of Transbaikalia in the 1950-60s;

- wave of accelerated liquidation of collective farms and their privatization (the beginning of 1990s) [24].

Farming can be characterized by very significant and diverse environmental consequences. Its influence on the natural environment of the Baikal region can be divided into several stages.

1) Primitive gathering which preceded to agriculture was widespread in the taiga zone with wide ecological niches and variety of plant conditions. Eneolithic period and the beginning of Bronze Age (3.8-3.0 thousand years ago), was marked by transition from gathering to agriculture.

2) The next stage is connected with the irrigated agriculture of the Barguts, who widely applied the advanced method of improving the culture of land use (II century AD). During this period, they introduced a network of small irrigation facilities for irrigating arid land. Unfortunately, this most effective method of land irrigation gradually lost its value.

3) Since 1950s, large-scale melioration of wetlands has been carried out. In particular, large boggy massifs of Mukhinsky wetland in the Ivolginsky, Kaltusny and Klukvennaya valleys in the Selenga delta, around the Koymor lakes in Tunkinskaya valley, as well as Oimur peatlands were drained. This sad experiment conducted out of good intentions caused a number of negative phenomena and disrupted the ecological balance.

Today, the consequences of drainage are more and more apparent. Salinity of saline soils is observed on drained massifs of Mukhinsky wetland, permafrost thawing is observed on Koymor lakes. Further on, the areas with thawed soil lead to dry landscapes of depleted vegetation with subsidences. During the period of precipitation peaty and silty soils soak in these areas, but in dry-weather period they crack. Therefore, reclamated wetlands turned out to be completely unacceptable for agricultural development.

4) The irrigation method of agricultural lands for vegetable crops did not quite justify itself, although it gave a certain positive effect. In the conditions of steppe and forest-steppe Transbaikalia irrigated lands gradually become useless due to soil salinization. Millennial orientation of Baikal region inhabitants towards agricultural development already has negative consequences. But the new drama can also appear on the peripheral parts of the region's ecosystem, where the natural resistance of mountain and foothill landscapes is significantly reduced, since the social and economic infrastructures here are only emerging. These areas may suffer unforeseen modifying of unique and untouched mountain and foothill landscapes.

Raising of water level in Baikal also caused irreparable harm to the environment of the region. According to various sources, 60 years ago backwater effect of the Irkutsk hydroelectric complex resulted in 0.8-1.2 $\mathrm{m}$ raising of the water level and flooding of the total area of over 1200 sq.km. Such increase led to changes in the natural course of the 
coast-forming processes, intensified erosion of the coast. All beaches turned out to be flooded and Baikal waves sharply increased the erosion of the shores. Caving of shore slopes led to intensification of old and emergence of new erosion processes. Frequent leveling of the lake led to erosion of many accumulative forms of the coast, which were formed for a long time. Some of them are completely degraded, others continue to recover thanks to increased sediment flow [18], [25], [26].

Since 2014 until the beginning of 2018 the water level in Baikal was abnormally decreasing. The experts consider the "difficult hydrological situation which developed in the basin of the lake" as the main reason. The minimum level - 455.86 $\mathrm{m}$ - at norm of $456 \mathrm{~m}$ was fixed in 2015. During this period the power engineering specialists proposed to reduce temporarily level by $20 \mathrm{~cm}$, however, according to the Buryat scientists this could lead to violation of the developed mechanisms of self-cleaning of the Baikal waters and damage to coastal ecosystems.

On January 1, 2018 the resolution of the Government of the Russian Federation No. 1667 "About extreme values of water level in Lake Baikal in 2018-2020" came into force. Despite protests of public ecological organizations, the range of allowed fluctuations of Baikal water level regulated by the Irkutsk hydroelectric power station was expanded to $2.3 \mathrm{~m}$ (between marks of $455.54 \mathrm{~m}$ and $457.83 \mathrm{~m}$ on the Pacific system of heights) - nearly 2.5 times more than former values.

"It is already noticed that because of more water leaving via turbines of the Irkutsk hydroelectric power station than it is necessary, the populations of local types of fishes and birds reduced approximately by a third. And Rosrybolovstvo counted that decrease in water level by $20 \mathrm{~cm}$ leads to reduction of quantity of fish in terms of money on one billion rubles per year, - says Igor Shkradyuk, the coordinator of ecologization of industry program of the Center of protection of the wild nature. For millions of years birds, fish, plants living on Baikal adapted to the mode of its life. Yes, during certain periods their number for the natural reasons decreased. For example, birds that build their nests on coast could lose them in some summer because of high water level. But it is one thing that this occurs in 7-10 years, and quite another when it appears every year" [27]. In other words, the construction of the Irkutsk hydroelectric station and further Angarsk cascade of hydropower stations resulted in transformation of the lake Baikal into an artificial reservoir with all ensuing consequences.

\section{CONCLUSION}

Hydrological conditions of the lake basin depend primarily on the terrain and climate. There are many rivers, lakes and mineral springs, but water resources are unevenly distributed. In most of its territory, the river network is relatively dense, although the steppe regions of the Selenga middle mountains are poorly watered. At the same time, intensive human activity, which occurs simultaneously with natural processes, significantly changes the environmental conditions in the Baikal region and disturbs the ecological balance established over the centuries. The influence of anthropogenic activities (deforestation, unsystematic plowing of the territory, mine workings, and other types of economic activity) significantly reduce the water-forming and water-regulating functions of natural landscapes. They cause sharp surface damage and destruction of topsoil as a result of irrational environmental management. Air and surface waters are polluted in mining areas; whereas, all these violations contribute to activation of erosion processes, dehydration of the surrounding area, etc. Therefore, the choice of the most optimal, from an environmental point of view, further development and transformation of the territory requires detailed landscape studies, including the studies on the degree of influence of natural components on the formation of river flow.

The article was an attempt to describe and assess the anthropogenic impact of mining and agricultural development on natural landscapes of the Baikal region. Protection of any landscape transformed by man or close to natural lies first of all in loss prevention of its resource and ecological potentials. The foremost attention should be paid to the "foundation" of the landscape - its morpholithogenic base [28]. Most often this foundation is modified in the process of extracting minerals from its depths. At the same time, the impact force exerted on the natural environment is very diverse. Spatial coverage of landscape transformation can also vary from single holes to huge quarries and fields. What is more, ore mining can be carried out in different ways. Mining method can disturb hydrological conditions, pollute ground and surface waters. But the greatest damage to the environment is caused by open-pit mining. The total disturbed area, where indigenous landscapes are completely destroyed, is 3 to 12 times larger than the area of the mine field itself [29]. In recent years, the scale and nature of mining in the Baikal region has increased significantly. That is why, in order to preserve the harmony of natural landscape, it is necessary to carry out geological work with minimum losses, not causing significant harm to the environment. As for the agriculture, harsh natural conditions of Transbaikalia (sharp continental climate, low rainfall) led to implementation of more efficient farming methods melioration, which were aimed at radical improvement of land. However, the cases considered in this article show that such measures were not always successful and led to further ecological disbalance.

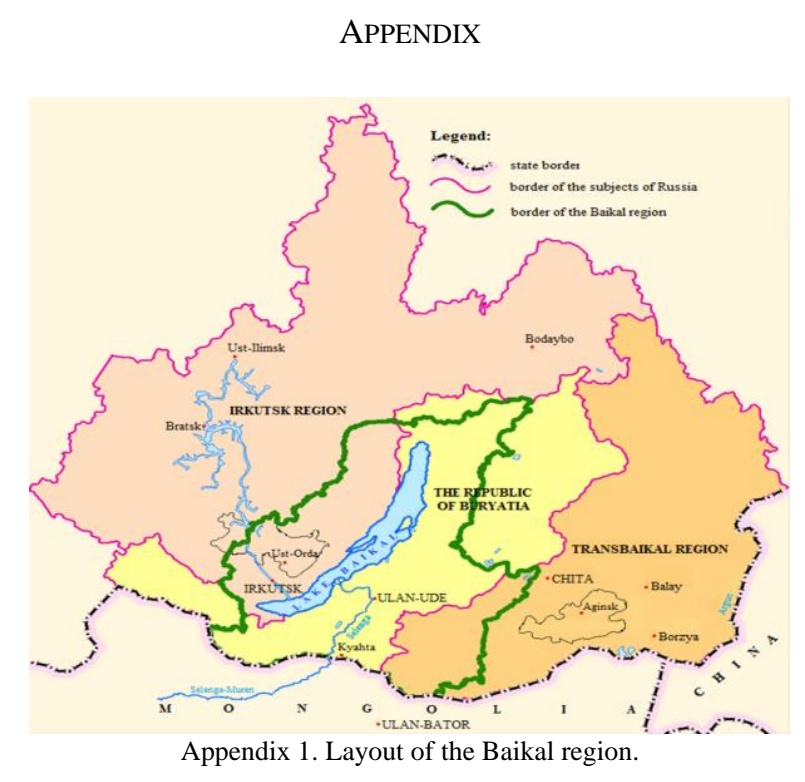




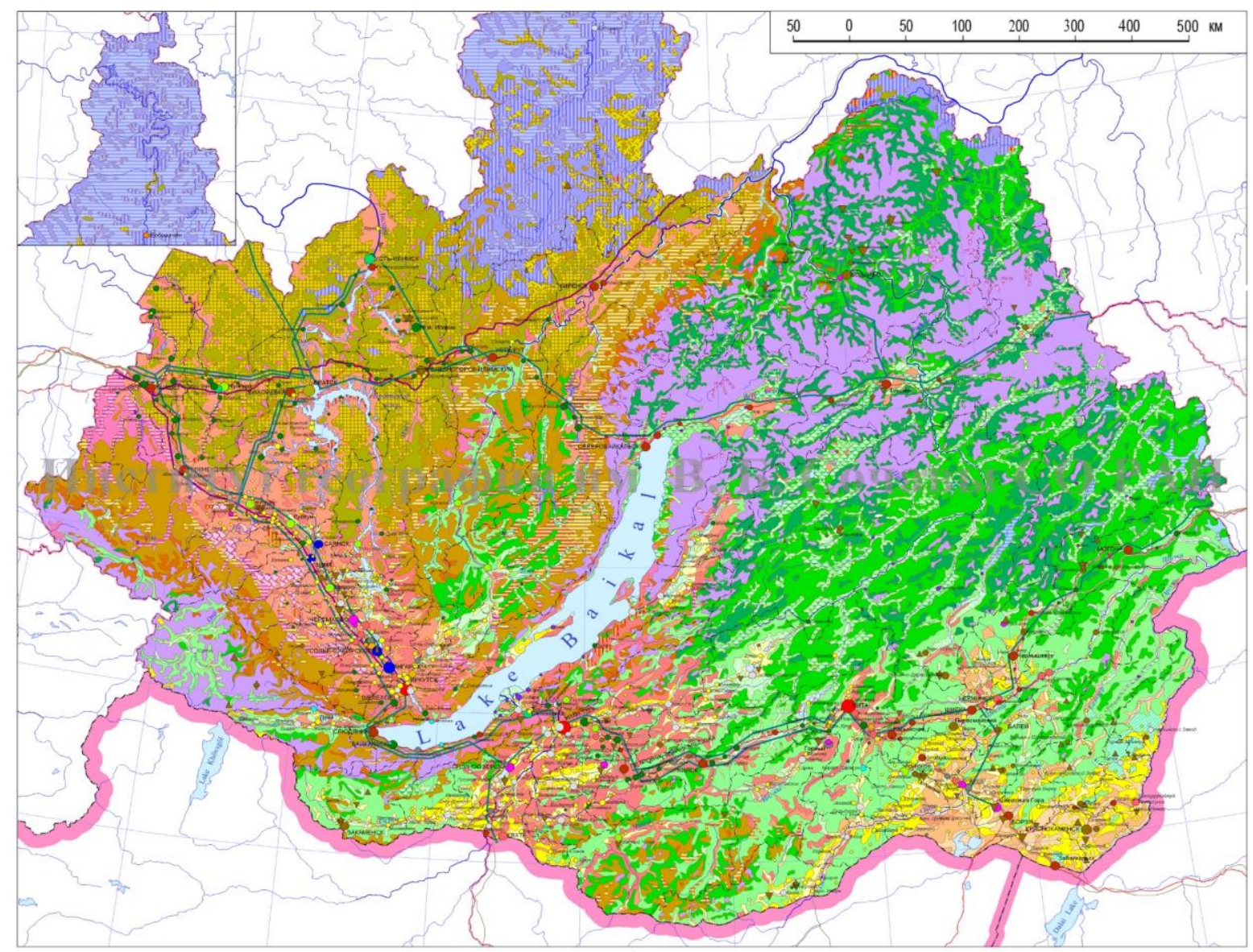

Appendix 2. Natural landscapes and their use.

BACKGROUND

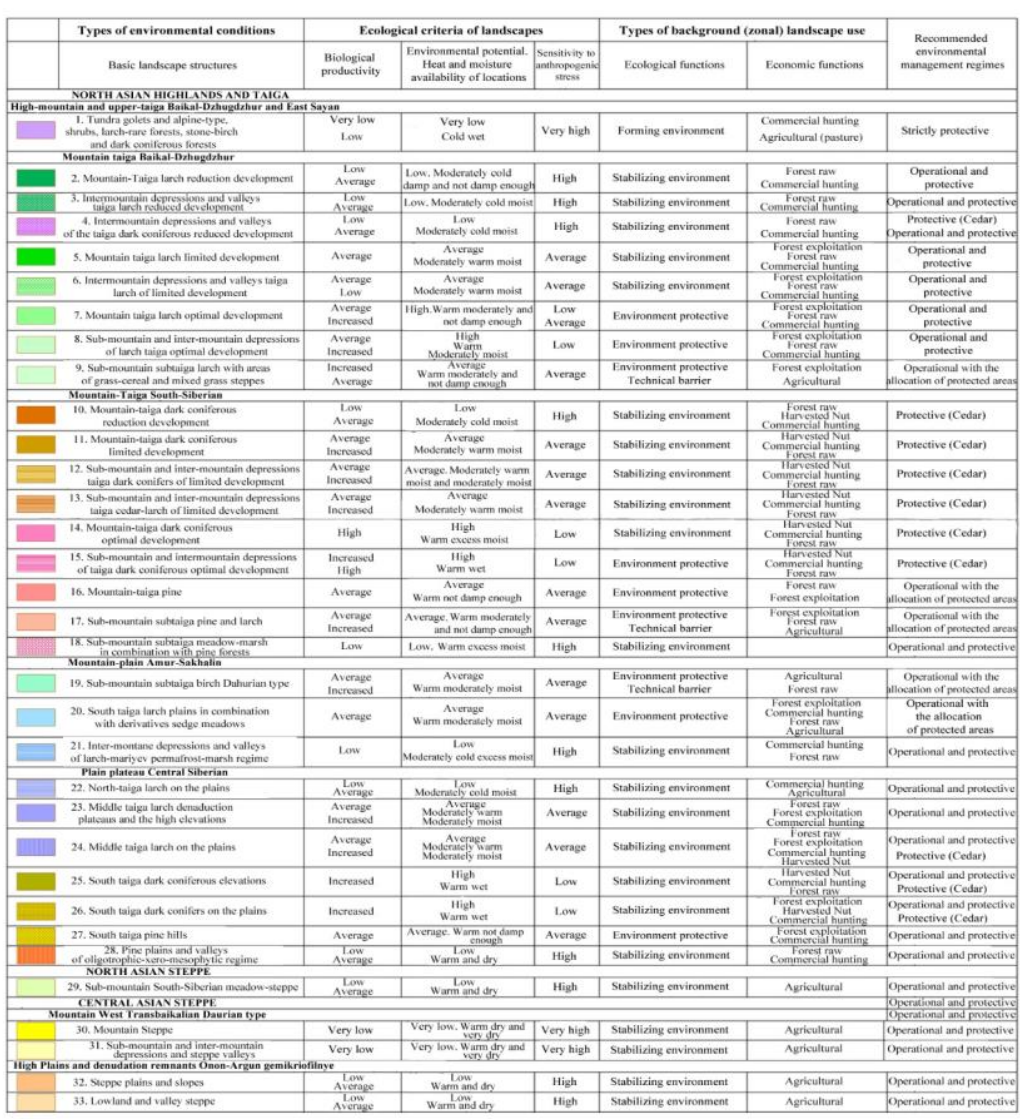

LOCALIZED

RESIDENTIAL-ECONOMIC

Industrial

- Mutrifinctional Industrial and transpor

Multifinctional Industist

- Mining industry

- Nonferemos vetallargy and Pulp and paper industry

- Pulp and paper and foreses chemical lindust

- Forest and woodworking Industry

- Oreser and woodsties industy in combination with Other industrits

Other industries

- Agroindustrial

Agricultural

- Commercial combined with agricultural

- Transpor (in large centers in combination with industrias

Number of inhabitants of settlements, thous.

over 300

from 100 to 300

from 50 to 100

from 10 to 50
from 5 to 10

from 5 to 10
from 2 to 5

from 1

less

Transport and communication

—_ Raliuass

\section{Z}

Subsoil use

Methods of extraction of minerals

$\checkmark$ Open (cureers, incisions, dredging)

A Underyound (mines, galleries)

1 Undergound (wells)

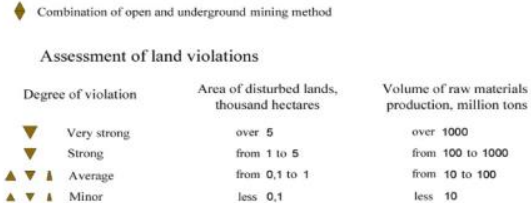

Appendix 3. Natural landscapes and their use 


\section{CONFLICT OF INTEREST}

The authors declare no conflict of interest.

\section{AUTHOR CONTRIBUTIONS}

O.A. Imetkhenov conducted the research; B.Ts. Dondukov analyzed the data; G.P. Dondukova wrote the paper; all authors had approved the final version.

\section{REFERENCES}

[1] A. B. Imetkhenov and A. K. Tulokhonov, Osobo ohranyaemye prirodnye territorii Buryatii [Specially protected areas of Buryatia], Ulan-Ude: BNC SO RAN, 1992, p. 151.

[2] I. V. Gordienko and M. A. Nefedyev, "Kurbino-Eravninskij rudnyj rajon Zapadnogo Zabaikalia: geologo-geofizicheskoe stroenie, tipy rudnyh mestorozhdenij, prognoznaya ocenka i perspektivy osvoeniya" [Kurbino-Eravninsky ore district of western Transbaikalia: geological and geophysical structure, types of ore deposits, natural assessment and development prospects], Geologia rudnyh mestorozhdenij [Geology of Ore Deposits], vol. 57, no. 2, 2015, pp. 114-124.

[3] S. G. Garmaeva, C. B. Gomboeva, G. I. Khanturgaeva, and V. Z. Tsyrenov, "Geoekologiya Baikalskoj prirodnoj territorii" [Geo-ecology of the Baikal Natural Territory], Bulletin of the Buryat state university. Biology. Geography, no. 4, 2008, pp. 157-160.

[4] O. A. Imetkhenov and S. Z. Gulgenov, "Ekologicheskaya ocenka antropogennogo vozdejstviya na landshafty Baikalskogo regiona' [Environmental assessment of the anthropogenic impact on the landscapes of the Baikal region], in International Proc. Innovacionnye podhody $k$ resheniyu problem «Sendajskoj ramochnoj programmy po snizheniyu riska bedstvij na 2015-2030 gody» [Innovative approaches to solving the problems of the Sendai Framework for Disaster Risk Reduction 2015-2030], Kazan, 2018, pp. 271-276.

[5] A. B. Imetkhenov, Priroda perekhodnoj zony na primere Baikalskogo regiona [The nature of the transition zone on the example of the Baikal region], Novosibirsk: Izd-vo SO RAN, 1997 p. 229.

[6] A. B. Imetkhenov and O. A. Imetkhenov, "Posledstviya antropogennogo vozdejstviya na prirodnuyu sredu Baikalskogo regiona" [Consequences of anthropogenic impact on the natural environment of the Baikal region], in International Proc. Sovremennye problemy etnoekologii i tradicionnogo prirodopolzovaniya [Current problems of ethnoecology and traditional nature management], Ulan-Ude, 2008, pp. 155-157.

[7] Maps of Baikal Region. Russian Geographical Society. [Online]. Available:

https://www.rgo.ru/en/irkutskoe-oblastnoe-otdelenie/proekty/karty

[8] I. Timofeev, N. Kosheleva, and N. Kasimov, "Contamination of soils by potentially toxic elements in the impact zone of tungsten-molybdenum ore mine in the Baikal region: A survey and risk assessment," Science of the Total Environment, vol. 642, 2018, pp. 63-76.

[9] Kholodninskoe Field. Nedra Dalnego Vostoka [Mineral resources of the Far East]. [Online]. Available: https://nedradv.ru/nedradv/invetsp/ ?obj=8cfab8ca24e0d950ab29a01d 55edde2d\#about

[10] Ozernoe Field. Nedra Dalnego Vostoka [Mineral resources of the Far East]. [Online]. Available: https://nedradv.ru/nedradv/invetsp/?obj= 9ca8e2d2ab6e71575d82c482dcff2688

[11] New operator of Ozernoe field development can begin extraction of zinc in 2022. (March 2019). Interfax. [Online]. Available: http://www.interfax-russia.ru/FarEast/news.asp?id=1012095

[12] Zharchikhinskoe Field. Nedra Dalnego Vostoka [Mineral resources of the Far East]. [Online]. Available: https://nedradv.ru/nedradv/invetsp /?obj=d63bd630c3a0d64877dd8a1ea42bb6d3\#about

[13] S. D. Shirapova and T. B. Tsyrendorzhieva, "Geoekologicheskij analiz proektnyh materialov namechaemoj khozyajstvennoj deyatelnosti po osvoeniyu Egitinskogo mestorozhdeniya plavikovogo shpata (Respublika Buryatia)" [Geo-ecological analysis of project materials of the planned economic activity for the development of the Egitsky fluorspar deposit (Republic of Buryatia)], Bulletin of VSGUTU, vol. 1, no. 68,2018 , pp. $30-36$.

[14] A. D. Abalakov and N. B. Bazarova, "Technogenic impact of mining industry on natural and social spheres in areas of passage of economic corridors "China-Mongolia-Russia," Advances in Social Science,
Education and Humanities Research (ASSEHR), vol. 312, 2019, pp. 1-5.

[15] A. B. Imetkhenov, "Antropogennaya transformaciya gornyh ekosistem Baikalskogo regiona" [Anthropogenic transformation of mountain ecosystems of the Baikal region], International Proceedings of Gory chelovek: $v$ poiskah ustojchivogo razvitiya [Mountains and man: in search of sustainable development], Barnaul, 1996, pp. 103-104.

[16] A. B. Imetkhenov, O. A. Imetkhenov, and V. D. Khandueva, "Mnogoletnie nablyudeniya za katastroficheskimi yavleniyami v Baikalskom regione" [Long-term observations of catastrophic events in the Baikal region], in Proc. Of Krasnoyarsk Pillars State Reserve, Devoted to 40 Anniversary of Reserve, Krasnoyarsk, 2009, pp. 80-85.

[17] Kolichestvo propavshih vo vremya navodneniya v Irkutskoj oblasti vyroslo [The number of missing during the flood in the Irkutsk region increased]. (2019). Interfax. [Online]. Available: https://www.interfax.ru/russia/669858

[18] A. B. Imetkhenov, Buryatia: Stihii i katastrofy [Buryatia: Forces and Catastrophes], Ulan-Ude: Izd-vo BGU, 2003, p. 197.

[19] T. A. Borisova and A. L. Voloshin, "Chrezvychajnye situacii prirodnogo kharaktera v Baikalskom regione. Seli" [Natural emergencies in the Baikal region. Mudflows], Bulletin of the Buryat state university. Biology. Geography, no. 4, 2015, pp. 50-54.

[20] A. K. Tulokhonov and S. D. Puntsukova, "Lesnye pozhary v respublike Buryatiya v usloviyah izmeneniya klimata" [Forest fires in the Republic of Buryatia under climate change], Obshchestvo: politika, ekonomika, pravo [Society: politics, economics, law], vol. 3, 2016, pp. 72-78.

[21] The lake Baikal basin, State of the Environment Report, Ulan-Ude: Pulse radio, 2015, p. 124.

[22] Zabaikalie. Svod materialov vysochajshe uchrezhdennoj komissii dlya izsledovaniya mestnago zemlevladeniya $i$ zemlepolzovaniya, pod predsdatelsvom stats-sekretarya Kulomzina, sostavil N.I. Razumov [Transbaikalia. The corpus of materials of the highest established commission for the investigation of local land tenure and land use, under the chairmanship of State Secretary Kulomzin, arranged by N.I. Razumov], S-Pb, 1899, p. 373.

[23] Buryatskaya ASSR v cifrah [The Buryat Autonomous Soviet Socialist Republic in numbers], Ulan-Ude: Buryat. kn. izd-vo, 1987, p. 156.

[24] Istoriya Buryatii [History of Buryatia], ed. B. V. Bazarov, Ulan-Ude: izd-vo BNC SO RAN, 2011, chapters 3, 5, 6, 7, 8, vol. 3.

[25] A. B. Imetkhenov, Katastroficheskie yavleniya v beregovoj zone Baikala [Catastrophic events in the coastal zone of Baikal], Ulan-Ude: Izd-vo Buryat. ped. in-ta, 1994, p. 65.

[26] A. K. Tulokhonov, Y. Z. Garmaev, and B. Z. Tsydypov, "Spatial and temporal dynamics of the Baikal coastal line caused by control of the lake level regime," Geography, Environment, Sustainability, 2013, vol. 06 , no. 02 , pp. 20-27.

[27] 2018 god: Dvenadcat' udarov po Baikalu. Chast' I [Twelve hits on Lake Baikal. Part 1]. Bellona. [Online]. Available: https://bellona.ru/2019/01/09/baikal-2018-1

[28] N. A. Solncev, "Problema ustojchivosti landshaftov" [The problem of landscape stability] Bulletin of Moscow university, Geography, no. 1, 1984, pp. 14-19.

[29] V. D. Gorlov, Osnovy okhrany prirody pri gornyh razrabotkah [Fundamentals of nature conservation in mining], Novocherkassk: Novocherkassky politech, 1977, p. 81.

Copyright $(2020$ by the authors. This is an open access article distributed under the Creative Commons Attribution License which permits unrestricted use, distribution, and reproduction in any medium, provided the original work is properly cited (CC BY 4.0).

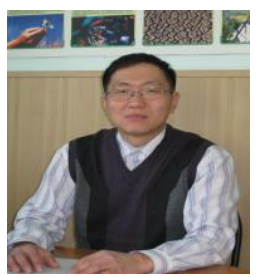

Oleg A. Imetkhenov was born in Ulan-Ude, the republic of Buryatia, USSR on January 14, 1977. In 1999, he graduated the Buryat State University, Ulan-Ude with a degree in geography. He defended $\mathrm{PhD}$ thesis "Geosystems of the high-mountainous part of the Eastern Sayan and the North-Eastern Pribaikalye" at the Buryat State University, and received the degree of candidate of geographical sciences in 2003.

$\mathrm{He}$ is an associate professor at the Department of Ecology, Subsoil Use and Life Safety at the East-Siberia State University of Technology and Management, Ulan-Ude, Republic of Buryatia. From 2002 to 2005 was a junior researcher at the state natural reserve "Dzherginsky," Kurumkansky district, the Republic of Buryatia. His academic interest are landscape mapping and environmental management of geosystems. 
Dr. Imetkhenov is the author of more than 90 scientific papers, 4 collective monographs and 1 textbook.

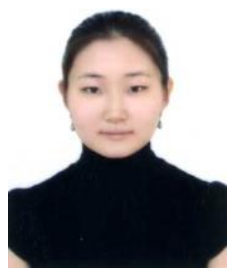

Galina P. Dondukova was born in Ulan-Ude, the republic of Buryatia, USSR on December 26, 1987. In 2009, she graduated the Buryat State University, Ulan-Ude with a degree in linguistics. In 2013 she received the degree of candidate of philological sciences at the Buryat State University, Ulan-Ude. In 2019 she defended a PhD thesis at the University of Warsaw, Poland and received the degree of doctor of Philosophy (in Literary Studies).

She is a senior researcher at the Department of Organization and Management of Scientific Researches at the East-Siberia State University of Technology and Management, Ulan-Ude, Republic of Buryatia. Her academic interest are environmental ethics, Buddhism, ethnic identity, Buryat literature.

Dr. Dondukova is the author of more than 15 scientific papers.

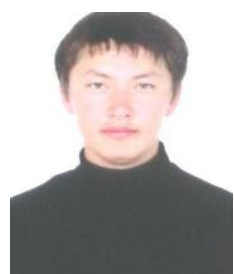

Bato Ts. Dondukov was born in Ulan-Ude, the republic of Buryatia, USSR on July 14, 1988. In 2010, he graduated the East-Siberian State Technological University, Ulan-Ude with a degree in Applied Informatics in Economics. In 2019 he defended a PhD thesis at the University of Warsaw, Poland and received the degree of doctor of philosophy (in culture and religion).

$\mathrm{He}$ is a junior researcher at the Department of Organization and Management of Scientific Researches at the East-Siberia State University of Technology and Management, Ulan-Ude, Republic of Buryatia. His academic interest are environmental ethics, Buddhism, Internet communities, ethnic identity.

Dr. Dondukov is the author of more than 15 scientific papers. 